\title{
Implementasi Sistem Informasi Prediksi Hasil Penjualan Perangkat Komputer Menggunakan Metode Double Exponential Smoothing
}

\author{
Nurul Adha Oktarini Saputri ${ }^{1}$, Nurul Huda ${ }^{2}$ \\ Fakultas Ilmu Komputer, Teknik Informatika, Universitas Bina Darma, Palembang, Indonesia \\ Email: nuruladhaos@binadarma.ac.id,2,"nurul_huda@binadarma.ac.id \\ Email Penulis Korespondensi: nurul_huda@binadarma.ac.id
}

\begin{abstract}
Abstrak-Prediksi merupakan suatu kegiatan untuk meramalkan suatu keadaan yang akan terjadi di masa mendatang dengan melalui pengujian di masa lalu. Salah satu cara untuk mendapatkan informasi penjualan dimasa depan yaitu dengan melakukan peramalan penjualan. Peramalan penjualan ini menggunakan metode Double Exponential Smoothing karena metode ini melakukan peramalan dengan cara mengadakan penghalusan atau pemulusan terhadap data masa lalu yaitu dengan mengambil rata-rata dari nilai beberapa tahun untuk menaksir nilai pada tahun yang akan datang dan metode ini menggunakan metode time serie. Hasil dari penelitian ini yaitu sistem informasi prediksi penjualan yang tepat, guna menentukan persediaan barang yang ada sesuai dengan permintaan (demand) agar tidak terjadi overstock atau kekurangan persediaan dimasa yang akan datang.
\end{abstract}

Kata Kunci: Prediksi, Penjualan, Double Exponential Smoothing

Abstract-Prediction is an activity to predict a situation that will occur in the future by passing tests in the past. One way to get sales information in the future is to make sales forecasting. This sales forecast uses the Double Exponential Smoothing method because this method predicts by smoothing or smoothing past data by taking an average of several years to estimate the value of the coming year and this method uses the time series method. The results of this study are the right sales prediction information system, in order to determine the existing inventory of goods in accordance with the demand (demand) so that there is no overstock or lack of inventory in the future.

Keywords: Prediction, Sales, Double Exponential Smoothing

\section{PENDAHULUAN}

Prediksi merupakan alat bantu yang paling efektif dan efisien dalam suatu perusahaan karna Prediksi merupakan suatu kegiatan untuk meramalkan suatu keadaan yang akan terjadi di masa mendatang dengan melalui pengujian di masa lalu[1]. prediksi juga merupakan pernyataan mengenai nilai yang akan datang dari variable seperti permintaan[2], Artinya ramalan adalah prediksi mengenai masa depan dengan dasar pengetahuan atau nilai masa lalu yang telah dipersiapkan. Prakiraan ramalan mencakup penggunaan data historis, dengan memproyeksikannya untuk masa depan yang menggunakan jenis model matematis[3]. Salah satu cara untuk mendapatkan informasi penjualan dimasa depan yaitu dengan melakukan peramalan penjualan. Kegiatan meramal atau forecast hasil penjualan dimasa depan merupakan salah satu usaha perusahaan sebagai dasar pengambilan keputusan strategis kelangsungan usaha. Semakin baik ramalan semakin baik pula mekanisme yang dapat diambil, dengan demikian dapat dihindari kekurangan/kehabisan barang. Metode Double Exponential Smoothing merupakan metode yang tepat dalam memprediksi atau meramal suatu penjualan karena metode ini melakukan peramalan dengan cara mengadakan penghalusan atau pemulusan terhadap data masa lalu yaitu dengan mengambil rata-rata dari nilai beberapa tahun untuk menaksir nilai pada tahun yang akan datang dan metode ini menggunakan metode time series[4].

Berdasarkan hasil penelitian [5]yang berjudul "Rancang Bangun Aplikasi Prediksi Penjualan Menggunakan Algoritma Double Exponential Smoothing Berbasis Web (Studi Kasus: Pt. Sanpak Unggul). Penelitian ini bertujuan untuk melakukan peramalan penjualan dimasa mendatang beserta fitur fitur aplikasi lainnya seperti kemampuan untuk menambahkan (insert), mengubah (edit), dan menghapus (delete) data produk dan ringkasan penjualan yang akan atau telah disimpan dalam suatu database untuk studi kasus perusahaan tertentu. Aplikasi yang dibangun menggunakan algoritma double exponential smoothing. Alasan pemanfaatan algoritma ini adalah nilai smoothing akan diperoleh tepat waktu sebelum data aktual saat data historis memiliki komponen trend. Oleh karena itu, untuk nilai smoothing tunggal, perlu ditambahkan nilai dari double smoothing untuk menyesuaikan trend tersebut. Metode yang dapat digunakan untuk memprediksi trend linear adalah metode dua parameter Holt. Pada metode Holt, nilainya bukan trend halus dari double smoothing secara langsung, melainkan penghalusan trend dilakukan dengan menggunakan parameter yang berbeda dengan yang digunakan untuk menghaluskan data aslinya. Hasil penelitian menunjukkan bahwa aplikasi yang dibangun memiliki persentase kesalahan sekitar $28,38 \%$. Aplikasi yang dibangun juga mampu memenuhi fitur-fitur yang dikehendaki oleh user dalam pemrosesan produk dan rekapitulasi".

Begitu juga menurut [6] dalam "Sistem Informasi Peramalan Penjualan Kripik Pisang Menggunakan Metode Double Exponential Smoothing Berbasis Web Pada Toko Tiga Putra Di Lumajang". Toko Tiga Putra merupakan usaha milik keluarga, usaha ini sudah dimulai dari tahun 2010 hingga sekarang. Permasalahan yang biasanya muncul di dalam usaha keripik pisang di Toko Tiga Putra adalah seringnya toko mengalami kekurangan stok sehingga tidak dapat memenuhi permintaan pelanggan dan bagaimana memprediksi hasil 
penjualan keripik pisang dimasa mendatang berdasarkan data yang telah direkam sebelumnya. Prediksi tersebut sangat berpengaruh pada keputusan untuk menentukan jumlah penjualan kripik pisang yang harus dijual oleh Toko Tiga Putra dibulan yang akan datang. Metode yang digunakan dalam penelitian ini adalah Double Exponential Smoothing, metode tersebut digunakan untuk menghitung peramalan penjualan kripik pisang. Tujuan dari penelitian ini yaitu terbangunnya sebuah Sistem Informasi Peramalan Penjualan Kripik Pisang pada Toko Tiga Putra Menggunakan Metode Double Exponential Smoothing. Penelitian menghasilkan sebuah aplikasi sistem informasi peramalan penjualan kripik pisang menggunakan metode Double exponential smoothing yang dapat digunakan untuk meramalkan jumlah penjualan kripik pisang yang dijual dimasa sekarang dan yang akan datang”.

Begitu juga dengan Toko Inter Media Komputer, merupakan perusahaan yang bergerak dibidang bisnis khusus perdagangan dengan menjual perangkat dan aksesoris komputer berbagai macam jenis dan tipe seperti laptop, perangkat komputer, keyboard, mouse, flashdisk, modem, dan alat perkantoran. Hal ini menyebabkan kebutuhan akan informasi ketersediaan barang yang sesuai dengan penjualan yang terjadi menjadi sangat penting. Apalagi mengingat barang-barang yang ada merupakan barang yang memiliki ukuran harga yang cukup mahal dan banyak diminati konsumen karena perubahan teknologi yang terus menerus semakin meningkat. Salah satu masalah yang dihadapi Inter Media Komputer yaitu kesulitan dalam menentukan stok barang sehingga menyebabkan tidak terpenuhinya permintaan konsumen terhadap barang yang dibutuhkan karena barang dicari tidak tersedia atau kehabisan stok untuk barang tertentu[7]. Hal ini dapat menyebabkan keuntungan perusahaan tersebut berkurang dan terdapat stok barang tidak laku karena sulitnya memprediksi permintaan konsumen akan kebutuhan teknologi.

Untuk mengatasi permasalahan tersebut dilakukan sebuah penelitian yaitu dengan membangun sistem informasi prediksi penjualan yang tepat, guna menentukan persediaan barang yang ada sesuai dengan permintaan (demand) agar tidak terjadi overstock atau kekurangan persediaan. Dan dengan adanya sistem informasi prediksi ini diharapkan dapat mengurangi terjadinya kekurangan dan kelebihan stok barang serta dapat memenuhi kebutuhan konsumen melalui informasi mengenai data hasil penjualan yang mengalami kenaikan dan penurunan pada periode yang akan datang sehingga dapat membantu pihak perusahaan dalam menentukan persediaan barang dengan lebih efesien.

\section{METODOLOGI PENELITIAN}

Dalam Memprediksi penjualan ini peneliti menggunakan metode Peramalan kuantitatif yaitu metode yang berhubungan dengan ilmu statistik dan matematika[8]. "Metode kuantitatif dikelompokan menjadi dua jenis yaitu : analisis sebab-akibat (Causal Methods ) yang didasarkan atas pengguna analisa pola hubungan antara variabel yang akan diperkirakan dengan variabel lain yang mempengaruhinya dan analisa deret berkala (Time Series ) yang pada umumnya selalu berdasarkan atas penggunaan analisa pola hubungan antara variabel yang akan diperkirakan dengan variabel waktu. Metode ini merupakan metode peramalan yang memperkirakan permintaan konsumen/penjualan periode yang akan datang dengan menggunakan data historis". Terdapat 3 peramalan dalam merencanakan penjualan dimasa yang akan datang, yaitu "peramalan ekonomi", "peramalan teknologi" dan "peramalan permintaan"[9] .

\subsection{Metode Pengumpulan Data}

Metode pengumpulan data adalah teknik atau cara-cara yang digunakan oleh peneliti untuk mengumpulkan data. Dalam hal ini, teknik pengumpulan data yang peneliti gunakan sebagai berikut[10];

1. Observasi (Pengamatan langsung)

Merupakan suatu cara pengumpulan data dengan cara melakukan pengamatan secara langsung ke objek penelitian untuk melihat dari dekat kegiatan yang dilakukan. Dalam hal ini, peneliti melakukan pengamatan secara langsung kepada objek penelitian tentang pelaksanaan dari kegiatan operasional pada Inter Media Komputer dan meminta data-data yang berhubungan dengan penelitian yang lakukan.

2. Interview (Wawancara)

Merupakan suatu cara pengumpulan data yang digunakan untuk memperoleh informasi langsung dari sumbernya. Dalam hal ini, peneliti bertanya langsung kepada karyawan Inter Media Komputer yang berisikan pertanyaan yang berhubungan dengan data-data yang dibutuhkan.

3. Studi Kepustakaan

Merupakan pengumpulan data yang berhubungan dengan objek yang diteliti serta bersumber dari buku-buku pedoman, literatur-literatur yang disusun oleh para ahli untuk melengkapi data yang diperlukan dalam penelitian ini.

\subsection{Metode Pengembangan Sistem}

Metode SDLC (System Development Life Cycle) atau sering disebut dengan metode Waterfall merupakan metode yang digunakan pada pengembangan sistem ini[11]. Langkah-langkah yang harus dilakukan pada metedologi waterfall adalah sebagai berikut : Analisis Kebutuhan, Disain, Pengkodean dan Pengujian. 


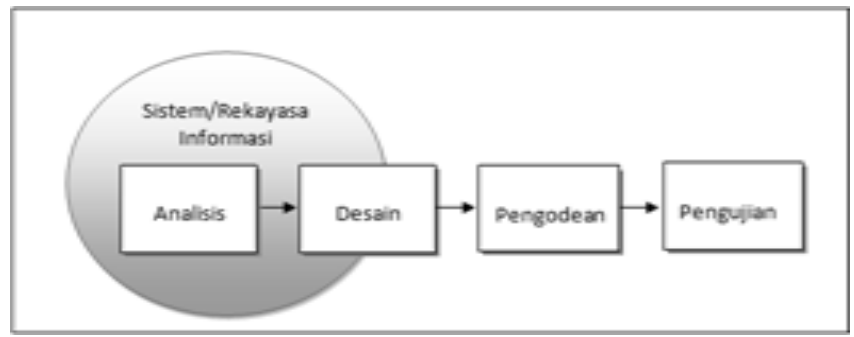

Gambar 1. Metode Waterfall

\section{HASIL DAN PEMBAHASAN}

Hasil yang didapat pada penelitian ini yaitu Sistem Informasi Prediksi Penjualan Perangkat Komputer. Berdasarkan metode yang dipakai maka tahap awal dari penelitian ini yaitu :

\subsection{Analisis Data}

Mengingat barang-barang yang ada merupakan barang yang memiliki ukuran harga yang cukup mahal dan banyak diminati konsumen karena perubahan teknologi yang terus menerus semakin meningkat. Salah satu masalah yang dihadapi Inter Media Komputer yaitu kesulitan dalam menentukan stok barang sehingga menyebabkan tidak terpenuhinya permintaan konsumen terhadap barang yang dibutuhkan karena barang dicari tidak tersedia atau kehabisan stok untuk barang tertentu. Hal ini dapat menyebabkan keuntungan perusahaan tersebut berkurang dan terdapat stok barang tidak laku karena sulitnya memprediksi permintaan konsumen akan kebutuhan teknologi. Berikut data penjualan 5 bulan terakhir leptop Acer seri 478GT dari bulan Juli sampai November 2017.

Tabel 1. Data Penjualan leptop Acer seri 478GT 5 bulan terakhir 2017

\begin{tabular}{cclc}
\hline $\mathrm{t}$ & Tahun & Bulan & Penjualan $\left(\mathrm{X}_{\mathrm{t}}\right)$ \\
\hline 1 & 2017 & Juli & 36 \\
2 & 2017 & Agustus & 39 \\
3 & 2017 & September & 40 \\
4 & 2017 & Oktober & 42 \\
5 & 2017 & November & 43 \\
\hline
\end{tabular}

Dengan menggunakan data pada tabel diatas, maka akan dihitung jumlah penjualan pada bulan Desember 2017, dengan nilai parameter alpha 0,2. Berikut rumus yang digunakan[12].

1. Menentukan nilai pemulusan Exponential Tunggal $\left(\mathrm{S}_{\mathrm{t}}^{\prime}\right)$

$$
S^{\prime} t=\alpha X t+(1-\alpha) S^{\prime} t-1
$$

$\mathrm{S}_{\mathrm{t}}=$ Nilai pemulusan exponential tunggal

$\alpha=$ Parameter pemulusan exponential

$\mathrm{X}_{\mathrm{t}}=$ Nilai riil periode $\mathrm{t}$

$S_{t-1}^{\prime}=$ Nilai pemulusan exponential sebelumnya.

2. Menentukan nilai pemulusan exponential ganda $\left(\mathrm{S}_{\mathrm{t}}{ }_{\mathrm{t}}\right)$

$$
S^{\prime \prime} t=\alpha S^{\prime} t+(1-\alpha) S^{\prime \prime} t-1
$$

$\mathrm{S}_{\mathrm{t}}{ }_{\mathrm{H}}=$ nilai pemulusan eksponential ganda

3. Menentukan besarnya konstanta $\left(\alpha_{t}\right)$

$$
\alpha t=S^{\prime} t+\left(S^{\prime} t-S^{\prime \prime} t\right)=2 S^{\prime} t-S^{\prime \prime} t
$$

$\alpha_{\mathrm{t}}=$ besarnya konstanta periode $\mathrm{t}$.

4. Menentukan besarnya Slope $\left(b_{t}\right)$

$$
b_{t}=\frac{\alpha}{\alpha-1}\left(S^{\prime} t-S^{\prime \prime} t\right)
$$

$\mathrm{b}_{\mathrm{t}}=$ slope/nilai tren dari data yang sesuai. 
JURNAL MEDIA INFORMATIKA BUDIDARMA

Volume 4, Nomor 3, Juli 2020, Page 806-814

ISSN 2614-5278 (media cetak), ISSN 2548-8368 (media online)

Available Online at https://ejurnal.stmik-budidarma.ac.id/index.php/mib DOI 10.30865/mib.v4i3.2253

5. Menentukan besarnya Forecast

$$
\mathrm{F}_{\mathrm{t}+\mathrm{m}}=\text { besarnya forecast }
$$

$$
F t+m=\alpha t+b t m
$$

Langkah-langkah perhitungan Double Exponential Smoothing menggunakan alpha 0,2

$$
S^{\prime} t=\alpha X t+(1-\alpha) S^{\prime} t-1
$$

$$
\begin{aligned}
& \mathrm{S}_{1}^{\prime}=36 \\
& \mathrm{~S}_{2}=(0,2) 39+(0,8) 36=36,6 \\
& \mathrm{~S}_{3}^{\prime}=(0,2) 40+(0,8) 36,6=37,28 \\
& \mathrm{~S}_{4}^{\prime}=(0,2) 42+(0,8) 37,28=38,22 \\
& \mathrm{~S}_{5}^{\prime}=(0,2) 43+(0,8) 38,22=39,18
\end{aligned}
$$

$$
S^{\prime \prime} t=\alpha S^{\prime} t+(1-\alpha) S^{\prime \prime} t-1
$$

$$
\begin{aligned}
& \mathrm{S}_{1}=36 \\
& \mathrm{~S}_{2}=(0,2) 36,6+(0,8) 36=36,12 \\
& \mathrm{~S}_{3}=(0,2) 37,28+(0,8) 36,12=36,35 \\
& \mathrm{~S}_{4}=(0,2) 38,22+(0,8) 36,35=36,73 \\
& \mathrm{~S}_{5}=(0,2) 39,18+(0,8) 36,73=37,22
\end{aligned}
$$

\begin{tabular}{|c|c|c|c|c|c|c|}
\hline Bulan & $\begin{array}{l}\text { Penjualan } \\
\text { (Xt) }\end{array}$ & $S^{\prime} t$ & S"t & $\alpha_{t}$ & $b_{t}$ & $\mathrm{Ft}$ \\
\hline Juli 2017 & 36 & 36 & 36 & 36 & 0 & \\
\hline Agustus 2017 & 39 & 36,6 & 36,12 & 37,08 & 0,12 & \\
\hline September 2017 & 40 & 37,28 & 36,35 & 38,21 & 0,23 & \\
\hline Oktober 2017 & 42 & 38,22 & 36,73 & 39,72 & 0,37 & \\
\hline November 2017 & 43 & 39,18 & 37,22 & 41,14 & 0,49 & \\
\hline \multicolumn{6}{|c|}{$\begin{array}{l}\text { Hasil Prediksi Bulan ke } 6 \text { Desember } 2017 \text { sebesar = } \\
\text { Ketepatan Peramalan MPE = }\end{array}$} & $\begin{array}{l}41,63 \\
-0,68\end{array}$ \\
\hline
\end{tabular}

$$
\alpha t=2 S^{\prime} t-S^{\prime \prime} t
$$

$$
\begin{aligned}
& \alpha_{1}=2(36)-36=36 \\
& \alpha_{2}=2(36,6)-36,12=37,08 \\
& \alpha_{3}=2(37,28)-36,35=38,21 \\
& \alpha_{4}=2(38,22)-36,73=39,72 \\
& \alpha_{5}=2(39,18)-37,22=41,14
\end{aligned}
$$

$$
b_{t}=\frac{\alpha}{\alpha-1}\left(S^{\prime} t-S^{\prime \prime} t\right)
$$

$$
\begin{aligned}
& \mathrm{b}_{1}=0 \\
& \mathrm{~b}_{2}=\frac{0,2}{0,8}(36,6-36,12)=0,12 \\
& \mathrm{~b}_{3}=\underline{0,2}(37,28-36,35)=0,23 \\
& \mathrm{~b}_{4}=\frac{0,2}{0,8}(38,22-36,73)=0,37 \\
& \mathrm{~b}_{5}=\frac{0,2}{0,8}(39,18-37,22)=0,49
\end{aligned}
$$

$$
F t+m=\alpha t+b t m
$$

$\mathrm{F}_{5+1}=41,14+0,49$

$\mathrm{F}_{6}=41,63$ dibulankan menjadi 42

Berikut hasil perhitungan Double Exponential Smoothing dalam bentuk tabel, dapat dilihat pada table 2.

Tabel 2. Hasil perhitungan Double Exponential Smoothing

\section{Menguji Ketepatan Hasil Prediksi}


JURNAL MEDIA INFORMATIKA BUDIDARMA

Volume 4, Nomor 3, Juli 2020, Page 806-814

ISSN 2614-5278 (media cetak), ISSN 2548-8368 (media online)

Available Online at https://ejurnal.stmik-budidarma.ac.id/index.php/mib

DOI 10.30865/mib.v4i3.2253

Untuk menguji sejauhmana ketepatan hasil prediksi atau tingkat kesalahan/error terkecil, dalam hal ini menggunakan menggunakan rumus dari MPE adalah sebagai berikut :

$$
M P E=\sum_{t}^{n} \frac{P E_{t}}{n}
$$

Keterangan :

$$
\begin{aligned}
& P E t=\text { Kesalahan persentase }=\frac{(\mathrm{Y} t-F t)}{Y t} \times 100 \\
& \text { et }=\text { Kesalahan periode } t=\mathrm{Y} t-F t \\
& Y t=\text { Data aktual periode } t \\
& \mathrm{n} \quad=\text { Banyak periode } t \text {. } \\
& P E_{t} \quad=\frac{(Y 6-F 6)}{Y 6} \times 100 \\
& P E_{13}=\frac{(40-41,63)}{40} \times 100 \\
& P E_{13}=-4,08 \\
& M P E=P E_{t} / n \\
& M P E=-4,08 / 6 \\
& M P E=-0,68
\end{aligned}
$$

\subsection{Disain Sistem}

Untuk melakukan pemodelan sistem ini peneliti menggunakan UML (Unified Modeling Language) seperti usecase diagram dan aktivity diagram [13].

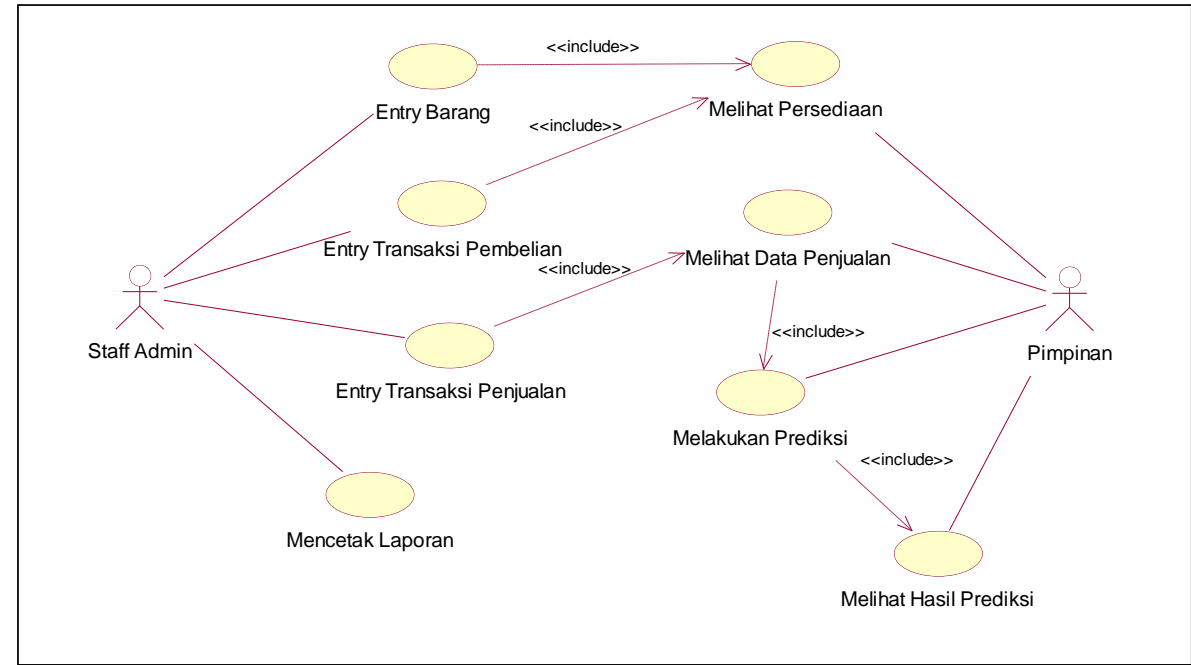

Gambar 2. Use Case Diagram

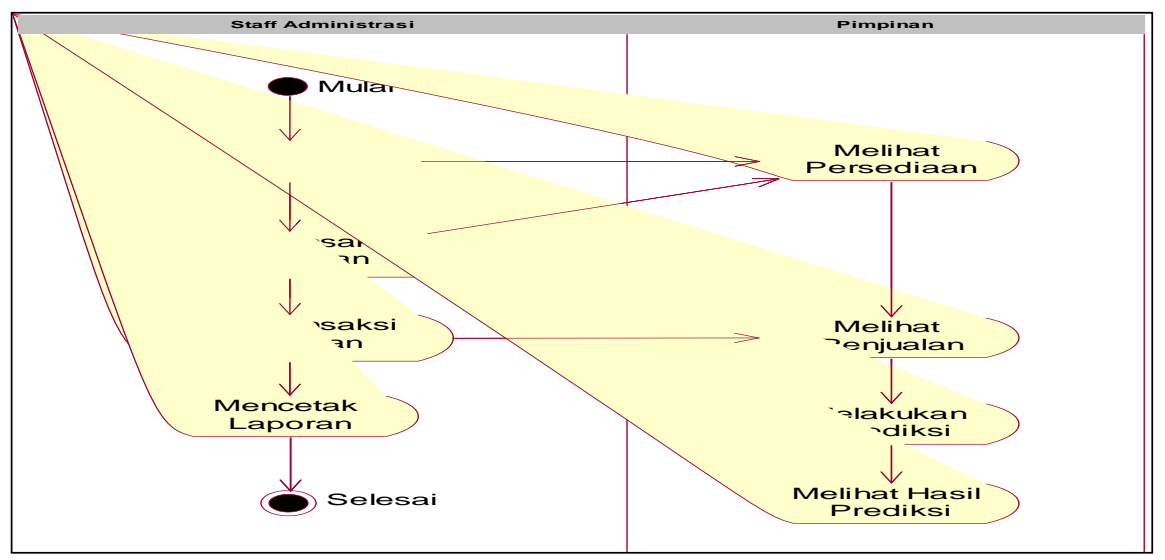

Gambar 3. Aktivity Diagram

\subsection{Pengkodean}

Nurul Adha Oktarini Saputri, Copyright (C2020, MIB, Page 810 
JURNAL MEDIA INFORMATIKA BUDIDARMA

Volume 4, Nomor 3, Juli 2020, Page 806-814

ISSN 2614-5278 (media cetak), ISSN 2548-8368 (media online)

Available Online at https://ejurnal.stmik-budidarma.ac.id/index.php/mib DOI 10.30865/mib.v4i3.2253

\section{A. Menu Form Log in}

Untuk masuk kemenu utama dapat dilakukan melalui form log in dengan mengisi username dan password, jika pengisian dilakukan dengan benar, maka sistem akan menampilkan menu user, dan sebaliknya jika pengisian username dan password salah maka sistem akan menampilkan pesan penolakkan bawah menu sistem tidak dapat diakses.Pengguna pada sistem informasi penjualan ini terdiri dari admin dan pimpinan.

Berikut Halaman form log in

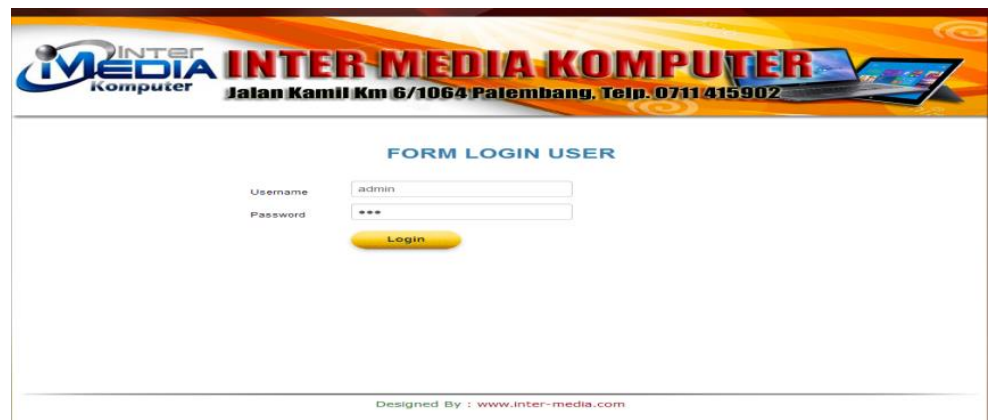

Gambar 4. Menu Form Log In

B. Menu Data Barang

Setelah masuk kemenu utama admin melakukan penginputan data barang, serta dapat melihat data persediaan barang dalam bentuk tabel

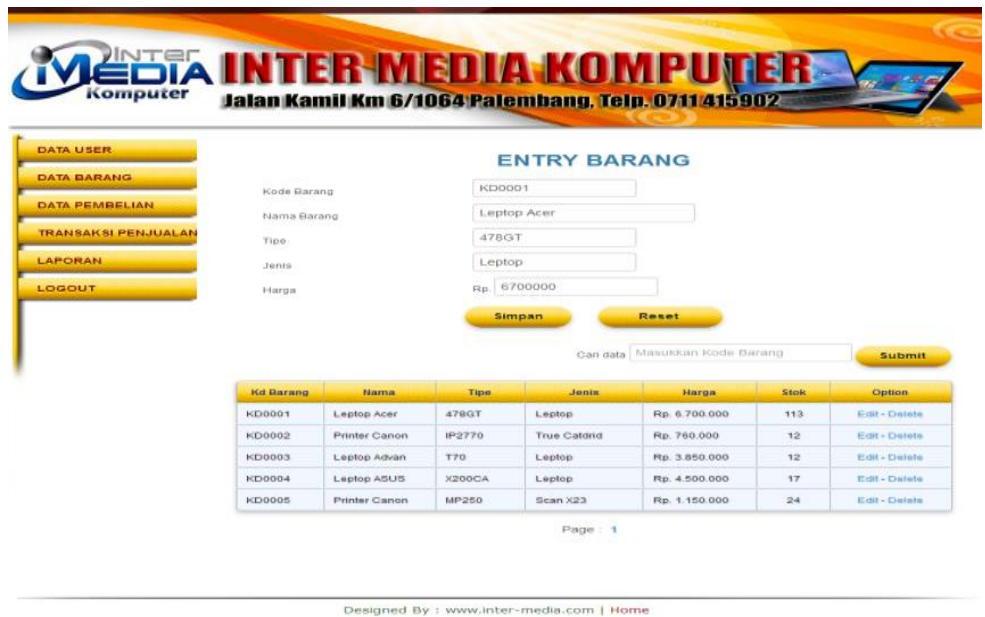

Gambar 5. Menu Data Barang

\section{Menu Transaksi Pembelian}

Untuk menambah persediaan barang, dapat dilakukan dengan memasukkan data pembelian, dengan mengklik tanggal pembelian, menentukan kodebarang, memasukkan jumlah pembelian, kemudian user mengklik tombol simpan.

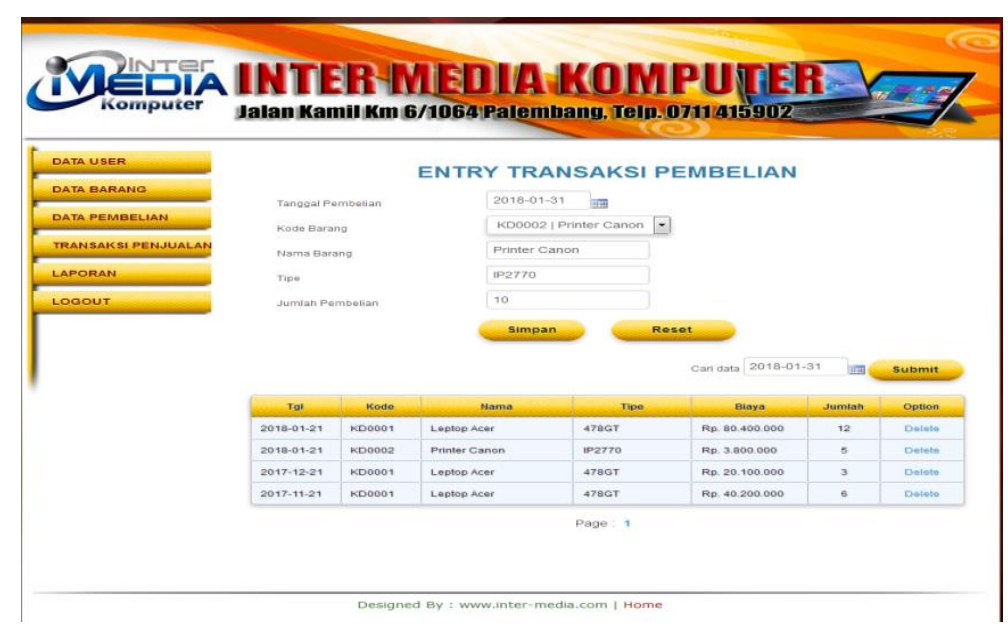

D. Menu Transaksi Penjualan

Gambar 6. Menu Transaksi Pembelian 
JURNAL MEDIA INFORMATIKA BUDIDARMA

Volume 4, Nomor 3, Juli 2020, Page 806-814

ISSN 2614-5278 (media cetak), ISSN 2548-8368 (media online)

Available Online at https://ejurnal.stmik-budidarma.ac.id/index.php/mib

DOI 10.30865/mib.v4i3.2253

Untuk menampilkan halaman transaksi, dilakukan dengan mengklik pada list menu transaksi, kemudian sistem akan menampilkan data transaksi penjualan dalam bentuk daftar tabel.

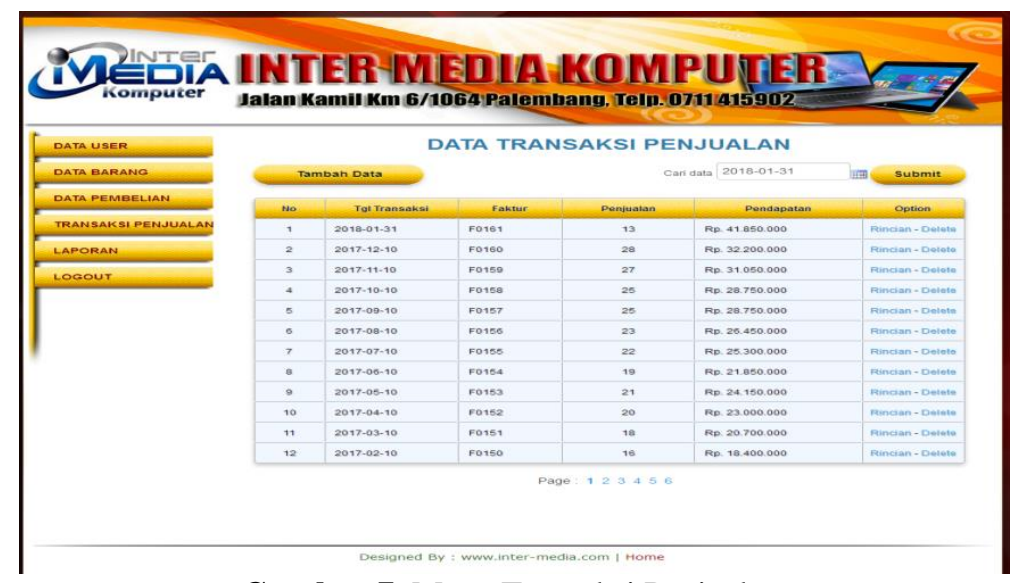

Gambar 7. Menu Transaksi Penjualan

\section{E. Menu Prediksi Penjualan}

Untuk melakukan prediksi penjualan pada periode mendatang, user harus menentukan barang dan memasukkan nilai parameter alpha dari 0.1 sampai 0.9 , kemudian dengan menentukan periode waktu bulan dan tahun.

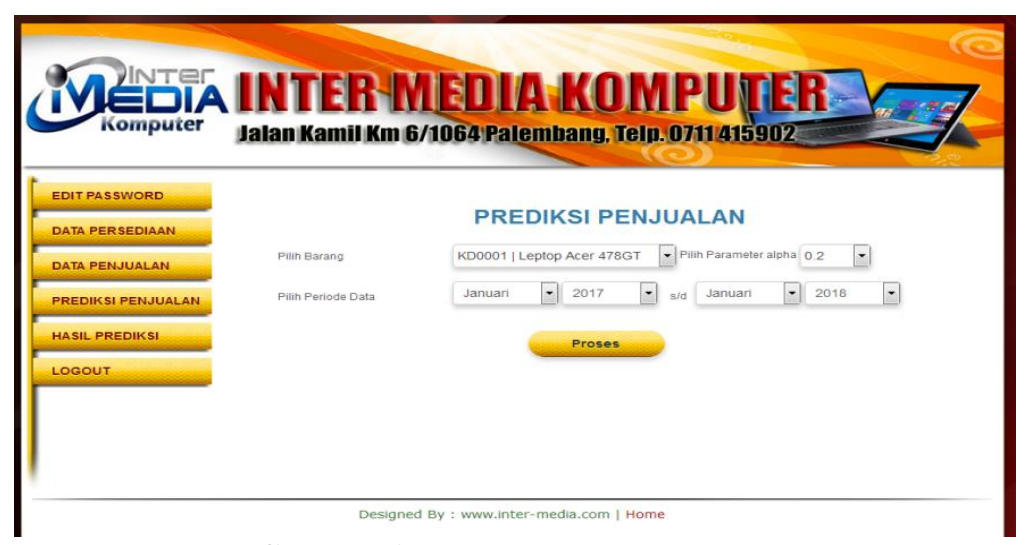

Gambar 8. Menu Prediksi Penjualan

\section{F. Menu Hasil Prediksi}

Berikut ini hasil prediksi penjualan pada periode mendatang, dengan hasil prediksi yang menampilkan perbandingan data penjualan dalam bentuk tabel dan grafik.

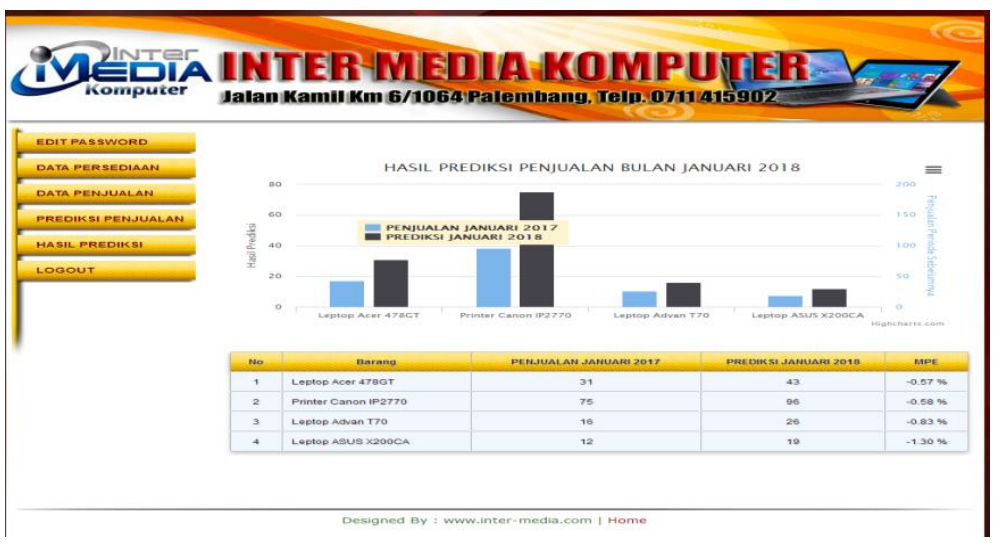

Gambar 9. Menu Hasil Prediksi Penjualan

\subsection{Pengujian}

Teknik pengujian yang digunakan dalam penelitian ini adalah pengujian blackbox [14]. Pengujian blackbox menitikberatkan pada fungsi sistem. Teknik ini digunakan untuk mengetahui apakah perangkat lunak berfungsi dengan benar. Hasil pengujian sistem menggunakan teknik blackbox dapat dilihat pada tabel 3 .

Tabel 3. Pengujian Software 
JURNAL MEDIA INFORMATIKA BUDIDARMA

Volume 4, Nomor 3, Juli 2020, Page 806-814

ISSN 2614-5278 (media cetak), ISSN 2548-8368 (media online)

Available Online at https://ejurnal.stmik-budidarma.ac.id/index.php/mib

DOI $10.30865 / \mathrm{mib} . v 4 \mathrm{i} 3.2253$

\begin{tabular}{|c|c|c|c|c|c|c|}
\hline No & \multicolumn{2}{|c|}{ Pengujian } & Hasil yang diharapkan & \multicolumn{2}{|l|}{ Hasil pengujian } & Kesimpulan \\
\hline 1 & Login & & Menampilkan menu utama & Sistem menampilkan & menu & Diterima \\
\hline 2 & $\begin{array}{l}\text { Simpan } \\
\text { Barang }\end{array}$ & data & $\begin{array}{l}\text { Sistem menampilkan form } \\
\text { data Barang }\end{array}$ & $\begin{array}{l}\text { Sistem menampilkan } \\
\text { data Barang }\end{array}$ & form & Diterima \\
\hline 3 & $\begin{array}{l}\text { Edit } \\
\text { Barang }\end{array}$ & data & $\begin{array}{l}\text { Sistem menampilkan form } \\
\text { data Barang }\end{array}$ & $\begin{array}{l}\text { Sistem menampilkan } \\
\text { data Barang }\end{array}$ & form & Diterima \\
\hline 4 & $\begin{array}{l}\text { Simpan } \\
\text { Pembelian }\end{array}$ & data & $\begin{array}{l}\text { Sistem menampilkan form } \\
\text { data Pembelian }\end{array}$ & $\begin{array}{l}\text { Sistem menampilkan } \\
\text { data Pembelian }\end{array}$ & form & Diterima \\
\hline 5 & $\begin{array}{l}\text { Edit } \\
\text { Pembelian }\end{array}$ & data & $\begin{array}{l}\text { Sistem menampilkan form } \\
\text { data Pembelian }\end{array}$ & $\begin{array}{l}\text { Sistem menampilkan } \\
\text { data Pembelian }\end{array}$ & form & Diterima \\
\hline 6 & $\begin{array}{l}\text { Simpan } \\
\text { Penjualan }\end{array}$ & data & $\begin{array}{l}\text { Sistem menampilkan form } \\
\text { data Penjualan }\end{array}$ & $\begin{array}{l}\text { Sistem menampilkan } \\
\text { data Penjualan }\end{array}$ & form & Diterima \\
\hline 7 & $\begin{array}{l}\text { Edit } \\
\text { Penjualan }\end{array}$ & data & $\begin{array}{l}\text { Sistem menampilkan form } \\
\text { data Penjualan }\end{array}$ & $\begin{array}{l}\text { Sistem menampilkan } \\
\text { data Penjualan }\end{array}$ & form & Diterima \\
\hline 8 & $\begin{array}{l}\text { Simpan } \\
\text { Prediksi } \\
\text { Penjualan }\end{array}$ & data & $\begin{array}{l}\text { Sistem menampilkan form } \\
\text { data Prediksi Penjualan }\end{array}$ & $\begin{array}{l}\text { Sistem menampilkan } \\
\text { data Prediksi Penjualan }\end{array}$ & form & Diterima \\
\hline 9 & $\begin{array}{l}\text { Edit } \\
\text { Prediksi } \\
\text { Penjualan }\end{array}$ & data & $\begin{array}{l}\text { Sistem menampilkan form } \\
\text { data Prediksi Penjualan }\end{array}$ & $\begin{array}{l}\text { Sistem menampilkan } \\
\text { data Prediksi Penjualan }\end{array}$ & form & Diterima \\
\hline 10 & Hasil Predi & & $\begin{array}{l}\text { Sistem menampilkan data } \\
\text { Laporan Hasil Prediksi }\end{array}$ & $\begin{array}{l}\text { Sistem menampilkan } \\
\text { Laporan Hasil Prediksi }\end{array}$ & data & Diterima \\
\hline
\end{tabular}

\subsection{Implementasi}

Pada tahap ini dilakukan implementasi terhadap sistem yang telah dibuat, sehingga terdapat perbedaaan terhadap penggunaan sistem antara sistem yang lama dengan sistem yang baru

Tabel 4. Implementasi Sistem

\section{Metode Lama}

\section{Metode Baru}

\begin{tabular}{ll}
\hline $\begin{array}{l}\text { Menginputkan data yang diramalkan } \\
\text { secara manual }\end{array}$ & Menginputkan data yang akan diramalkan berdasarkan sistems \\
$\begin{array}{l}\text { Menghitung rata-rata penjualan } \\
\text { setiap satu bulan }\end{array}$ & $\begin{array}{l}\text { Dengan sekali menekan tombol hitung, hasil data langsung di } \\
\text { tampilkan layar monitor klik } \\
\text { simpan akan secara otomatis menampilkan halaman } \\
\text { peramalan }\end{array}$ \\
$\begin{array}{l}\text { Menghitung rata-rata penjualan } \\
\text { selama setahun }\end{array}$ & $\begin{array}{l}\text { Dengan mengklik menu prediksi dan menginputkan bulan dan tahun } \\
\text { maka akan tampil hasil prediksi pertahun }\end{array}$ \\
$\begin{array}{l}\text { Hasil rata-rata penjualan selama } \\
\text { setahun digunakan sebagai } \\
\text { pendukung untuk memprediksi } \\
\text { penjualan Perangkat Komputer } \\
\text { untuk tahun berikutnya }\end{array}$ & $\begin{array}{l}\text { Hasil Prediksi Penjualan Perangkat Komputer selama setahun dapat } \\
\text { dilihat dalam bentuk grafik, sehingga pemimpin dapat mengambil } \\
\text { keputusan untuk prediksi penjualan selanjutnya }\end{array}$ \\
\hline
\end{tabular}

\section{KESIMPULAN}

Kesimpulan yang dapat diambil dari hasil sistem informasi prediksi penjualan, yaitu : Sistem informasi yang dihasilkan berupa Sistem Informasi prediksi penjualan perangkat komputer pada Inter Media. pada sistem informasi ini terdapat form prediksi penjualan yang berfungsi untuk memprediksikan jumlah penjualan pada periode yang akan datang dengan menggunakan perhitungan rumus dari Double Exponential Smoothing menggunakan data historis, data penjualan periode sebelumnya, dengan proses pengambilan data berdasarkan periode bulan dan tahun. Dengan adanya sistem informasi prediksi ini dapat mengurangi terjadinya kekurangan dan kelebihan stok barang serta dapat memenuhi kebutuhan konsumen melalui informasi mengenai data hasil penjualan yang mengalami kenaikan dan penurunan pada periode yang akan datang sehingga dapat membantu pihak perusahaan mengambil keputusan dalam menentukan persediaan barang dengan lebih efesien.

\section{REFERENCES}


JURNAL MEDIA INFORMATIKA BUDIDARMA

Volume 4, Nomor 3, Juli 2020, Page 806-814

ISSN 2614-5278 (media cetak), ISSN 2548-8368 (media online)

Available Online at https://ejurnal.stmik-budidarma.ac.id/index.php/mib

DOI 10.30865/mib.v4i3.2253

[1] A. Zamzam, "Analisis Jumlah Calon Mahasiswa Baru Di Fakultas Ekonomi Universitas Muhammadiyah Sumatera Utara," 2011.

[2] S. C. Stevenson, W. J., \& Shoung, Operations Management: an Asian Perspective. Jakarta: Salemba Empat, 2013.

[3] S. Syofian, Metode Penelitian Kuantitatif dilengkapi Perbandingan Perhitungan Manual \& SPSS. Jakarta: Kencana Prenadamedia Group, 2013.

[4] S. Purba, Analisis Kebutuhan Pasar dan Prediksi Penjualan, 2 ed. Erlangga, 2011.

[5] H. Richard, John; Seng, "RANCANG BANGUN APLIKASI PREDIKSI PENJUALAN MENGGUNAKAN ALGORITMA DOUBLE EXPONENTIAL SMOOTHING BERBASIS WEB (STUDI KASUS: PT. SANPAK UNGGUL)," J. Inform., vol. 14, no. 1, 2017.

[6] D. S. D, Marjuki;Maknunah, Jauharul; Utsalina, "Sistem Informasi Peramalan Penjualan Kripik Pisang Menggunakan Metode Double Exponential Smoothing Berbasis Webpada Toko Tiga Putra Di Lumajang," in Seminar Nasional Sistem Informasi, 2017.

[7] R. Rasmila, Rasmila; Amalia, "SISTEM INFORMASI PENENTUAN PERSIAPAN STOK OBAT MENGGUNAKAN WEIGHTED MOVING AVERAGE,”Sistemasi, vol. 8, no. 3, hal. 465-478, 2019.

[8] S. Alfarisi, "Sistem Prediksi Penjualan Gamis Toko Qitaz Menggunakan Metode Single Exponential Smoothing," JABE (Journal Appl. Bus. Econ., vol. 4, no. 1, hal. 80-95, 2017.

[9] B. Heizer, J., ; Render, Manajemen Operasi: Manajemen Keberlangsungan dan Rantai Pasokan, 11 ed. Jakarta: Salemba Empat, 2015.

[10] Riduwan, Belajar Mudah Penelitian untuk Guru-Karyawan dan Peneliti Pemula. Bandung: CV. Alfabeta, 2012.

[11] N. Huda dan R. Amalia, "Implementasi Sistem Informasi Inventaris Barang pada PT.PLN (Persero) Palembang," J. Sisfokom, vol. 9, no. 1, hal. 13-19, 2020.

[12] R. V. Lieberty, Annastasya; Imbar, "Sistem Informasi Meramalkan Penjualan Barang Dengan Metode Double Exponential Smoothing (Studi kasus: PD. Padalarang Jaya)," J. Tek. Inform. dan Sist. Inf., vol. 1, no. 1, 2015.

[13] N. Huda, "SISTEM INFORMASI WISATA SUMATERA SELATAN BERBASIS MOBILE," J. Tek. Inform. Politek. Sekayu, vol. 7, no. 2, hal. 51-56, 2017.

[14] R. Amalia dan N. Huda, "Sistem Informasi Pengarsipan Surat Masuk dan Surat Keluar Pada Dinas Tenaga Kerja dan Transmigrasi Kabupaten Musi Banyuasin," Media Inform. Budi Darma, vol. 4, no. 2, hal. 363-368, 2020. 